\title{
CZY NAPRAWDE BYŁY TO AWANTURY? INTERWENCJE POLSKIE W MOŁDAWII W LATACH 1595-1616
}

\author{
ILONA CZAMAŃSKA
}

\begin{abstract}
Were they really brawls? Polish interventions in Moldavia in the years 1595-1616. This paper was written in connection with the thesis that Polish interventions in Moldavia conducted in the years 1595-1616 were a result of the private policy of first Jan Zamoyski, and later the magnates — sons-in-law of Jeremy Movila. By analyzing the political and legal situation of the hospodars of Moldavia from the Movila dynasty towards the Polish king, I try to prove that all interventions were either completely or unofficially connected with the state policy of the Republic of Poland. The last intervention in the years 1615-1616 was the most controversial one, but the lack of support for it was not due to political reasons, but to personal ones.
\end{abstract}

STRESZCZENIE. Niniejszy artykuł powstał w związku z ciągle obecną i powtarzaną przez badaczy tezą, że polskie interwencje w Mołdawii prowadzone w latach 1595-1616 były rezultatem prywatnej polityki najpierw Jana Zamoyskiego, a później magnatów — zięciów Jeremiego Mohyły. Poprzez analizę sytuacji politycznoprawnej hospodarów Mołdawii z dynastii Mohyłów wobec króla Polski i jej interpretacji staram się udowodnić, że wszystkie interwencje albo w zupełny, albo w nieoficjalny sposób były powiązane z polityką państwową Rzeczypospolitej. Najbardziej kontrowersyjna była ostatnia interwencja z lat 1615-1616, jednak brak poparcia dla niej nie wynikał z przyczyn politycznych, lecz personalnych.

Author: Ilona Czamańska, Uniwersytet im. Adama Mickiewicza w Poznaniu, Wydział Historii, ul. Uniwersytetu Poznańskiego 7, 61-614 Poznań, ORCID iD: https://orcid.org/0000-0002-0492-0854

Słowa kluczowe: Mołdawia, Mohyłowie, interwencje polskie w Mołdawii, Jan Zamoyski, Stefan Potocki, Michał Wiśniowiecki, Samuel Korecki

Keywords: Moldavia, Movila, Polish interventions in Moldavia, Jan Zamoyski, Stefan Potocki, Michał Wiśniowiecki, Samuel Korecki

Balcanica Posnaniensia. Acta et studia, XXVIII/2, Poznań 2021, Wydawnictwo Wydziału Historii UAM, pp. 57 79, ISBN 978-83-66355-84-2, ISSN 0239-4278. Polish text with summaries in English and Polish

doi.org/10.14746/bp.2021.28.20

Już od momentu swojego powstania jako państwa Mołdawia stanowiła ważny element w polityce Polski także z innymi państwami, jak Węgry, a później Imperium Osmańskie. Wpływ sytuacji w Mołdawii na relacje polsko-tureckie zaczął się już w połowie XV wieku i raz po raz dawał o sobie znać w ciągu XVI stulecia, ostatecznie przeważał jednak wspólny interes polityczny polegający na unikaniu konfliktu. W końcu XVI wieku ta tendencja zaczyna się zmieniać. Wpłynęło na to wiele czyn- 
ników: ekspansja Turcji osmańskiej na północne wybrzeża Morza Czarnego i Morza Kaspijskiego, nasilający się konflikt Rzeczypospolitej z Chanatem Krymskim, przemiany gospodarczo-społeczne na byłych ziemiach litewskich przyłączonych do Korony, w tym tworzenie się Siczy Zaporoskiej jako organizacji samorządowej Kozaków. Następuje też nowa aktywizacja Osmanów na odcinku węgiersko-chorwackim, którą upatrywałabym jako rezultat utworzonego w 1580 roku ejaletu Bośni oraz wpływów wywodzących się stamtąd wielkich wezyrów i innych wysokich urzędników osmańskich. Lokalny początkowo konflikt na pograniczu bośniacko-chorwackim, jaki wybuchł w roku 1591, po włączeniu się w roku 1593 cesarza Rudolfa II przerodził się w wojnę osmańsko-cesarską, która ciągnęła się do 1606 roku.

Rzeczpospolita początkowo nie zajęła wobec tego konfliktu jasno sprecyzowanego stanowiska. Stosunki z państwem osmańskim były coraz trudniejsze. Dopiero w październiku 1591 roku zawarty został pierwszy za panowania Zygmunta III Wazy układ pokojowy z państwem osmańskim ${ }^{1} \mathrm{i}$ ceniono fakt, że Rzeczpospolita jako jedyne państwo europejskie cieszyła się takim pokojem bez opłaty trybutu². Jednak obawa wybuchu wojny ciągle istniała ze względu na konflikt z Tatarami, coraz większą aktywność kozacką i niestabilną sytuację w Mołdawii. Ponadto projekty ligi antytureckiej wysuwane przez Stefana Batorego stawiały państwo polskie w gronie potencjalnych jej członków. Dlatego też zarówno przed, jak i po zawarciu układu pokojowego trwały rozmowy z Habsburgami na temat ewentualnej współpracy wojskowej nie doprowadziły one jednak do żadnego konkretnego rezultatu ze względu na konflikt interesów dotyczący głównie księstw rumuńskich. Habsburgowie rościli sobie do nich pretensje jako spadkobiercy korony węgierskiej, natomiast dla Rzeczypospolitej był to jedyny kierunek uzyskania jakichkolwiek profitów w przypadku zwycięstwa ${ }^{3}$. Tymczasem poszukiwania sojuszników przez cesarza Rudolfa II doprowadziły do przejścia na jego stronę młodego księcia siedmiogrodzkiego Zygmunta Batorego. Dotychczasowa proosmańska polityka Siedmiogrodu uległa zmianie o $180^{\circ}$. Batory pozbył się przeciwników politycznych także wśród własnej rodziny ${ }^{4}$ i podjął bardzo skuteczne działania zmierzające do podporządkowania sobie księstw rumuńskich. Chętnie do tego sojuszu przystąpił hospodar wołoski Michał Waleczny, który dostrzegł w tym szansę na oddłużenie siebie i swego państwa. Hospodar mołdawski Aron Tyran też nie

1 D. Kołodziejczyk, Ottoman-Polish diplomatic relations, BRILL, Leyden-Boston-Köln 2000, s. 284-293 (dokument Murada III, 10-18.10.1591); ibidem, s. 294-297 (dokument ratyfikacyjny Zygmunta III, 15.01.1592; E. Hurmuzaki, Documente privitoare la istoria românilor, t. 3, cz. 1, București 1880, s. $160-162$.

2 Podkreślał to w jednej ze swych mów Jan Zamoyski. Mowa datowana mylnie na r. 1596 niewątpliwie jednak musi pochodzić sprzed r. 1595; Biblioteka Ossolineum, rkps 2354.

3 V. Ciobanu, La cumpănă de veacuri (Ţările române în contextul politicii poloneze la sfirsșitul secolului al XVI-lea şi începutul secolului al XVII-lea), Iaşi 1991, s. 96.

${ }^{4}$ M.in. E. Hurmuzaki, Documente privitoare la istoria românilor, t. 3, cz. 2, Bucureşti 1889, s. 52 56 (raporty weneckie, 15.10.1594 , 25.10.1594); A. Veress, Documente privitoare la istoria Ardealului, Moldovei şi Ţării Româneşti, t. 4, Bucureşti 1932, s. 130-136 (raport N. do Wiednia, wrzesień 1594, s. 136); L. Bazylow, Siedmiogród a Polska, 1576-1613, Warszawa 1967, s. 71. 
odżegnywał się od współpracy z cesarzem przeciw Osmanom ${ }^{5}$, a nawet na przełomie 1594 i 1595 roku wspólnie z oddziałami siedmiogrodzkimi i Kozakami spustoszył okolice Tighinii i Białogrodu ${ }^{6}$. Działania te kontynuował wiosną. W kwietniu 1595 roku wspólnie z Kozakami obległ Tighnię (Bender) ${ }^{7}$.

Działania Arona wywołały niepokój Zygmunta III, który w całej tej sytuacji zajmował stanowisko wyczekujące obawiając się wkroczenia Turków do Mołdawii. Interesów polskich na dworze hospodara pilnował jego szwagier Orzechowski, który w imieniu króla wynegocjował przekazanie mu Chocimia, zmarł jednak wkrótce po przyjeździe do tej twierdzy ${ }^{8}$.

Tymczasem Aron zdecydowanie odmówił uznania zwierzchnictwa Zygmunta Batorego i przyjazdu na sejm siedmiogrodzki ${ }^{9}$. Prawdopodobnie na tym tle doszło do konfliktu między hospodarem a jego hetmanem Stefanem Răzvanem. W rezultacie 6 maja 1595 roku Stefan Răzvan, najprawdopodobniej w porozumieniu z księciem siedmiogrodzkim, dokonał zamachu, aresztował hospodara i odesłał do Siedmiogrodu, sam zaś objął tron w Jassach. Nowy hospodar przejął władzę bez jakiejkolwiek konsultacji z osmańskim suzerenem, przeciwnie uznał zwierzchnictwo Zygmunta Batorego, natomiast Aron na rozkaz tego ostatniego został zamordowany ${ }^{10}$.

Państwo osmańskie nie mogło pozostać bierne wobec tych wydarzeń, zwłaszcza że w styczniu 1595 roku władzę tam objął młody i energiczny Mehmed III. W maju 1595 roku zapadła decyzja o likwidacji samodzielności obydwu państw i zamianie ich w regularne ejalety osmańskie. Sułtan Mehmed III mianował Satyrdżi Mehmeda paszę bejlerbejem Wołoszczyzny, a Dżafera paszę, byłego zarządcę Szyrwanu, bejlerbejem Mołdawii. Ostatecznie jednak, chcąc pozyskać do współdziałania chana krymskiego zdecydowano się powierzyć stanowisko bejlerbeja Mołdawii jego siostrzeńcowi Ahmedowi, sandżakbejowi Benderu'11. Zmiana na stanowisku wezyra, jaka nastąpiła w lipcu tego roku, nie spowodowała zmiany zamiarów Porty odnośnie

5 A. Veress, Documente, t. 4, s. 142 (doniesienia z Pragi z 25.10.1594); ibidem, s. 147-150 (papież Klemens VIII do Francesca Aldobrandiniego).

6 Ibidem, s. 175-176.

7 Ibidem, s. 198-199 (doniesienia Marca Verniera ze Stambułu, 19.04.1595).

8 I. Corfus, Mihai Viteazul şi Polonii cu documente înedide în anexe, Bucureşti 1937, s. 203 i 207 (J. Bojanowski do Krzysztofa Radziwiłła, 07.04.1595 i tenże do Mikołaja Krzysztofa Radziwiłła, 29.04.1595).

9 A. Veress, Documente, t. 4, s. 203-232; I. Corfus, Mihai Viteazul şi Polonii, s. 15.

10 I. Corfus, Mihai Viteazul şi Polonii, s. 208 (A. Taranowski do ks. Pstrokońskiego); ibidem, s. 211 (J. Potocki do J. Zamoyskiego); A. Veress, Documente, t. 4, s. 222-223 (S. Genga do Ferdynanda, wielkiego księcia Toskanii, 25.05.1595); M. Costin, Latopis Ziemi Mołdawskiej i inne utwory historyczne, tłum. wstęp i komentarze I. Czamańska, s. 103-104.

11 Elementa ad fontium editiones, t. 27, Romae 1972, s. 127 (N. do Ferdynanda, wielkiego księcia Toskanii, w tytule: Etrurii, b. m. i d.); C. Rotman-Bulgaru, Relaţiile Moldovei cu Imperiul Otoman la începutul secolului al XVII-lea, „Revista de Istorie” 1976, t. 29, nr 5, s. 682. Zob. też listy Ahmeda paszy do Zygmunta III z około 15.12.1597: AGAD, AKW, dz. tur., kart. 484, nr 809. Streszczenie pol. w: Z. Abrahamowicz, Katalog dokumentów tureckich, t. 1 (Dokumenty do dziejów Polski i krajów ościennych w latach 1455-1672), Warszawa 1959, s. 230-231. 
państw rumuńskich i wojska tureckie wkroczyły na Wołoszczyznę. Wprawdzie hospodar Michał stoczył z forpocztą wojsk tureckich pomyślną bitwę pod Călugăreni (23 sierpnia), jednak wobec przeważających sił wroga zmuszony był wycofać się do Siedmiogrodu.

Stefan Răzvan poczuł się zagrożony możliwością ataku tureckiego, a w szczególności najazdu chana krymskiego, jednakże ani hospodar wołoski, ani książę siedmiogrodzki nie mogli udzielić mu pomocy. Zwrócił się wówczas z prośbą o pomoc także i do Jana Zamoyskiego ${ }^{12}$, ten jednak uznał, że zaangażowanie się po jego stronie uzurpatora nie leży w interesie Rzeczypospolitej. Mołdawscy przyjaciele kanclerza i hetmana koronnego przebywający wówczas na emigracji w Polsce musieli go poinformować, że Stefan Răzvan nie miał on żadnych praw do tronu, w dodatku był niskiego, podobno cygańskiego, pochodzenia. Jego ścisłe podporządkowanie się księciu siedmiogrodzkiemu oraz podatność na wpływy habsburskie były tajemnicą Poliszynela. Jednak zarówno Zygmunt III, jak i Zamoyski zdawali sobie sprawę z niebezpieczeństwa, jakie groziło Rzeczypospolitej w przypadku opanowania Mołdawii przez wojska tatarsko-tureckie. Król uznał słusznie, że „lubo by do wojny z Turczynem nam przyszło lepiej by i bezpieczniej pewnie dla wielu i ważnych przyczyn za granicą i przy cudzej żywności i przy Dunaju odpor dawać mocy pogańskiej. Także i do zatrzymania pokoju snadniej by mając to w ręku przyść mogło"13. Podjęto więc natychmiast przygotowania do wkroczenia do Mołdawii, ale nie po to, by udzielić pomocy skonfliktowanemu z Imperium Osmańskim hospodarowi, lecz przeciwnie, by go z tronu mołdawskiego usunąć, osadzić własnego hospodara i obsadzić ważniejsze strategicznie miejsca polskim wojskiem.

Jan Zamoyski, działając niewątpliwie w pełnym porozumieniu z królem, zdecydował się osadzić na tamtejszym tronie swojego osobistego przyjaciela Jeremiego Mohyłę ${ }^{14}$. Ten bojar mołdawski, jako wielki dwornik za czasów Piotra Kulawego, przez wiele lat bardzo dobrze współpracował z Polakami, w tym czasie natomiast przebywał na emigracji w Rzeczypospolitej i posiadał od 1593 roku polski indygenat ${ }^{15}$. Fama głosiła, że przez matkę był spokrewniony z hospodarem Piotrem Rareşem, co stawiało go w nielicznym gronie uprawnionych do tronu mołdawskiego ${ }^{16}$.

12 AGAD, Archiwum Zamoyskich [dalej: AZ] 634, nr 30 (Deklaracja pîrcalaba Lupula, 25.07.1595).

13 I. Corfus, Mihai Viteazul şi Polonii, s. 212 (Zygmunt III do senatorów, 18.05.1595).

14 Na temat związków Jana Zamoyskiego i Jeremiego Mohyły: I. Czamańska, Caracterul legăturilor lui Jan Zamoyski cu Movileştii, „Arhiva Genealogică” 1996, t. 3(8), nr 3-4, s. 307-312; toż [w:] Movileştii. Istorie şi spiritualitate româneasca, t. 1 (Casa noastra Movileasca), Sfânta Manastire Suceviţa 2006, s. 115-120; idem, Între familie şi Stat. Relaţiile familiale ale dinastiei Movileştilor în Polonia, [w:] Movileştii. Istorie şi spiritualitate româneasca, t. 2 (Casa noastra Movileasca), Sfânta Manastire Suceviţa 2006, s. 263-272.

15 Volumina Constitutionum, t. 1 (1550-1609), t. 2 (1587-1609), wyd. S. Grodziski, Warszawa 2008, s. 202.

16 Jak szeroko rozpowszechniano informację o hospodarskim pochodzeniu Jeremiego Mohyły świadczyć może list ks. Sessa do Filipa II z 29 stycznia 1596 r.: ...Estefano generalmente mal quisto i ombre baxo de nacimiento, i el Jeremias de Ilinage de los antiguos Vayvodas: Al. Ciorănescu, Documente privitoare la istoria românilor culese din arhivele din Simancas, Bucureşti 1940, s. 126. 
Kiedy zapadła decyzja w sprawie poparcia Jeremiego Mohyły na tron mołdawski nie jest zupełnie jasne. Początki panowania Jeremiego Mohyły w Mołdawii datuje się najczęściej na początek września, jednak pierwszy jego list do króla polskiego, w którym podpisał się jako hospodar mołdawski, datowany jest już 1 lipca i to z Suczawy. Ta ostatnia data kłóci się jednak wyraźnie z wszystkimi innymi informacjami, najprawdopodobniej musiała nastąpić pomyłka w dacie miesięcznej lub rocznej, albo też złe jej odczytanie ${ }^{17}$.

Oddziały polskie przygotowywane przez Zamoyskiego były gotowe do wkroczenia do Mołdawii dopiero w końcu sierpnia. Przed tym, w dniu 27 sierpnia 1595 roku, Jeremi Mohyła złożył przysięgę, że po objęciu tronu mołdawskiego uzna zwierzchnictwo króla polskiego ${ }^{18}$.

Wydaje się, że wkraczając do Mołdawii Zamoyski nie miał konkretnych planów dotyczących polityki osmańskiej, cel był jeden: nie dopuścić do bezpośredniego włączenia ziem mołdawskich do Imperium Osmańskiego i osadzić tam przychylnego królowi polskiemu hospodara, a gdyby trzeba było stoczyć wojnę prowadzić ją na obcym terenie. Priorytetem było jednak zachowanie pokoju z państwem osmańskim. Dlatego jednym z pierwszych działań Zamoyskiego po wkroczeniu do Mołdawii było wysłanie gońca do Sinana paszy z zapewnieniem o chęci zachowania pokoju i usunięciu wrogiego Osmanom hospodara.

Bitwa pod Cecorą stoczona z wojskami tatarsko-tureckimi, które wkroczyły tam $\mathrm{w}$ celu organizacji prowincji tureckiej, pozostała nierozstrzygnięta $\mathrm{z}$ wykazaniem pewnej przewagi wojsk polskich ${ }^{19}$. Dowódca osmański, Ahmed pasza, okazał się wyjątkowo skłonny do porozumienia, w istocie bowiem nie był zainteresowany tworzeniem prowincji, która kontrolowałaby Chanat Krymski i Tatarów Budziackich. Bez większych trudności wynegocjowano więc odstąpienie państwa osmańskiego od zamiaru zamiany Mołdawii w ejalet osmański i zgodę na przejęcie w niej władzy przez Jeremiego Mohyłę na podobnych zasadach jak poprzedni hospodarowie ${ }^{20}$. Wprowadzony siłą hospodar został nie tylko zaakceptowany, ale uzyskał mocną po-

17 E. Hurmuzaki, Documente, supl. 2, t. 1, s. 342 (Jeremi Mohyła do Zygmunta III, 01.07.1595).

18 AGAD, AR II, nr 312; E. Hurmuzaki, Documente, supl. 2, t. 1, s. 344-345.

19 Na temat przebiegu bitwy i negocjacji zob. E. Hurmuzaki, Documente, supl. 2, t. 1, s. 355-357 (Jan Zamoyski do króla Zygmunta III, 24.10.1595). Relacja ta powstała najprawdopodobniej na bazie diariusza opublikowanego przez J. Jasnowskiego, Dwie relacje z wyprawy Zamoyskiego pod Cecorę w r. 1595, „Przegląd Historyczno-Wojskowy” 1938, t. 10, z. 2, s. 240-242. Znacznie obszerniejszy opis dał Paweł Piaskowski; ibidem, s. 241-255. Spośród opracowań zob. J. Sas, Wyprawa Zamoyskiego na Mołdawię, „Przegląd Powszechny” 1897, t. 56, z. 10, s. 74-89; Z. Spieralski, Awantury mołdawskie, Warszawa 1967, s. 145-148; L. Bazylow, Siedmiogród a Polska, s. 82-85; D. Milewski, Między patronatem a wspótpracarelacje Jana Zamoyskiego i hospodara mołdawskiego Jeremiego Mohyty, ,Wieki Stare i Nowe” 2012, tom specjalny, s. 11-31. Ciekawym źródłem do dziejów kampanii jest też utwór literacki Piotra Cieklińskiego Wołoska Ziemia, zob. I. Czamańska, Orzeł biały zwycięzca. ,, Wołoska Ziemia” Piotra Cieklińskiego nowa próba interpretacji, [w:] Eruditio et interpretatio, Poznań 1997, s. 309-320.

20 D. Kołodziejczyk, Ottoman-Polish diplomatic relations, s. 300-302 (dokument porozumienia, 22.10.1595); E. Hurmuzaki, Documente, supl. 2, t. 1, s. 353-354. Omówienie: D. Skorupa, Stosunki polsko-tatarskie 1595-1623, Warszawa 2004, s. 62-63. 
zycję. Ważną w tym rolę odegrał on sam ze swoimi zdolnościami politycznymi (przekazanie chanowi 7 wsi) ${ }^{21}$, jak też prawdopodobnie jego kapikichaja w Stambule Ion Caraiman $^{22}$. Uległość osmańska wynikała też niewątpliwie z potrzeby zablokowana ewentualnego sojuszu polsko-habsburskiego. Polacy próbowali to wykorzystać i doprowadzić do układu gwarantującego polski wpływ na obsadę stanowiska hospodara w Mołdawii23 ${ }^{23}$, co częściowo się udało. W układzie z 1598 roku wynegocjowanym przez Szczęsnego Herburta znalazło się wprawdzie zastrzeżenie wyłącznego prawa sułtana do mianowania hospodara, ale także zapis o zachowaniu Jeremiego Mohyły na tronie mołdawskim, o ile nie sprzeniewierzy się wierności Porcie i gwarancji po jego śmierci przejęcia władzy przez jego syna ${ }^{24}$. Był to duży postęp ponieważ po raz pierwszy tego rodzaju porozumienie zostało zapisane w traktacie.

Z powyższego wynika wyraźnie, że interwencja wojsk koronnych w Mołdawii w roku 1595 była koniecznością. Osadzenie Jeremiego Mohyły na tronie, mimo istnienia jego osobistych przyjacielskich relacji z Janem Zamoyskim, było rezultatem oficjalnych działań Rzeczypospolitej, która potwierdziła to układami międzynarodowymi.

Sytuacja polityczno-prawna Jeremiego Mohyły była złożona. Formalnie znalazł się pod zwierzchnictwem sułtana i przysięga złożona Zygmuntowi III i Rzeczypospolitej przestała obowiązywać, nieformalnie jednak była ona przestrzegana przez obie strony: mołdawską i polską ${ }^{25}$. W szczegółach zmieniała się też w zależności od niestabilnej sytuacji w regionie i równie niestabilnych planów politycznych Rzeczypospolitej wobec Imperium Osmańskiego, mimo oficjalnie trwającego pokoju. I tak w 1597 roku posłowie mołdawscy przybyli na sejm Rzeczypospolitej, potwierdzili przysię-

21 M. Costin, Latopis, s. 104-105.

22 I. D. Condurachi, Solii şi agenţi ai domnilor Moldovei la Poartă în secolul al XVII-lea, Bucureşti 1920, s. 34.

23 W instrukcji poselskiej dla Stanisława Gólskiego b. d. [1596] zobowiązano posła do Porty, by przypomniał o dawnych polskich prawach do Mołdawii, a Jeśliby cesarz turecki nam wołoskiej ziemi ustapić nie chciat, tedy na tym stanać może, aby $w$ Wołoszech nigdy basza stawion nie byt, ale żeby byt chrześcijanin podany od nas, któryby dań cesarzowi płacił taka, jako Aleksander za Solimana dawat, bo to wynoszenie tych dani ziemię zniszczyło; AGAD, LL 27, k. 59-61, tu k. 61; druk: I. Corfus, Documente privitoare la istoria românilor culese din arhivele polone. Secolul al XVI-lea, Bucureşti 1979, s. 379382, tu 381. W instrukcji dla Feliksa Herburta z 08.05.1598 czytamy m.in.: Aby wojewoda do Wołoch, a jako oni zową Bogdanu, mianowany był od nas i potomków naszych królów polskich dawany, ażeby dalej nie podnoszono [dani] nad tę, która była za Solimana cesarza; AGAD, LL 27, k. 65-66, druk I. Corfus, Documente... Secolul al XVI-lea, s. 387.

24 D. Kołodziejczyk, Ottoman-Polish diplomatic relations, s. 312-323, tu s. 322 (dokument układu z 04.08.1598); tekst polski: AGAD, LL 27, k. 138 v.-142v., tu s. 141.

25 Zygmunt III w liście do cesarza Rudolfa, 8 stycznia 1599 r. pisał: securitatem Moldaviae et Jeremiae Palatini, qui est in clientela et patrocinio nostro exemplum vetera Moldaviae confirmata; AGAD, LL 27, k. 90v. Ciekawe uwagi na temat statusu Mołdawii za rządów Jeremiego Mohyły zob. C. A. Bobicescu, Unia, inkorporacja czy lenno? Kilka uwag o stosunkach Mołdawii z Rzeczapospolita podczas panowania Jeremiego Mohity (1595-1606), [w:] Rzeczpospolita w XVII-XVIII wieku. Państwo czy wspólnota?, red. B. Dybaś, P. Hanczewski, T. Kempa, Toruń 2007, s. 219-239. 
gę wierności i zwrócili się o pomoc w obronie granic ${ }^{26}$. Wprawdzie sejm ten niczego nie uchwalił w tej sprawie, jednak Polacy poczuwali się do obowiązku obrony wprowadzonego przez siebie hospodara, obie strony uważały to za rzecz naturalną ${ }^{27}$, część oddziałów polskich, nieliczna wprawdzie, pozostała na służbie Mohyły od 1595 roku. Było to niezbędne, ponieważ rządy Jeremiego Mohyły były kilkakrotnie poważnie zagrożone.

Pierwsze poważne zagrożenie nastąpiło jeszcze w grudniu 1595 roku, gdy wygnany z kraju Stefan Răzvan powrócił do kraju z wojskiem siedmiogrodzkim. Został on pokonany 12 grudnia pod Suczawą przy poważnym udziale wojsk polskich pozostawionych z rozkazu hetmanów ${ }^{28}$. Mimo pokonania Stefana Răzvana i wbicia go na pal jako uzurpatora pozostał konflikt z księciem siedmiogrodzkim Zygmuntem Batorym oraz jego sojusznikiem hospodarem wołoskim Michałem Walecznym.

O ile Batory, cierpiący prawdopodobnie na chorobę dwubiegunową i wiele innych chorób, wycofując się w następnych latach z aktywnej polityki przestał stanowić zagrożenie, o tyle wołoski Michał stopniowo wyrósł na największego wroga Mohyły. Podłoże tego konfliktu było najprawdopodobniej złożone. W grę wchodziły zarówno kwestie polityczne, jak też osobiste i (może to przede wszystkim) ambicjonalne. Istotny wpływ na rozwój tego konfliktu miało objęcie z końcem marca 1599 roku tronu siedmiogrodzkiego przez biskupa warmińskiego i kardynała Andrzeja Batorego.

Nowy książę siedmiogrodzki, mimo iż wychowany na polskim dworze króla Stefana, posiadający polski indygenat i wielu przyjaciół w Polsce z Janem Zamoyskim na czele, uważany niekiedy za polskiego figuranta ${ }^{29}$, bynajmniej nie był polską marionetką. Tron siedmiogrodzki przejął wbrew porozumieniom swego poprzednika z cesarzem Rudolfem bez polskiej pomocy, wręcz przeciwnie, król Zygmunt III wyraźnie dystansował się od jego działań podkreślając, że nie ma z tym nic wspólne$\mathrm{go}^{30}$. Ponieważ nigdy nie został oficjalnie zaakceptowany przez cesarza, to nie był też oficjalnie uznany przez króla polskiego, co utrudniało współdziałanie ${ }^{31}$. W tej sy-

26 Diariusze sejmowe z roku 1597, [w:] Scriptores Rerum Polonicarum, wyd. E. Barwiński, t. 20, Kraków 1907; J. Rzońca, Sejmy z lat 1597 i 1598. Część I: Bezowocny sejm z 1597 roku, Warszawa-Wroclaw 1989, s. 92-93.

27 Jeremi Mohyła w liście do starosty podolskiego Jana Potockiego z 13.06.1597, informując o grożącym mu niebezpieczeństwie, wyraźnie spodziewał się obrony z jego strony; AGAD, AZ, 2879, s. $9-12$.

28 Najdokładniejszy i najwartościowszy opis bitwy przedstawił jej uczestnik Stanisław Chański w liście do arcybiskupa Stanisława Karnkowskiego, Suczawa, 08.02.1596; I. Corfus, Mihai Viteazul şi Polonii, s. 217-221.

29 Z. Spieralski, Awantury mołdawskie, Warszawa 1967, s. 150; P. P. Panaitescu, Mihai Viteazul, Bucureşti 2002, s. 148.

30 Krótko po objęciu tronu siedmiogrodzkiego przez Andrzeja Batorego podkanclerzy Piotr Tylicki pisał do Jana Zamoyskiego: Ta odmiana siedmigrodzka boje sie, by nas nie uczyniła podejrzanych, zwłaszcza, że pod tenże czas nasz indygena $w$ siedmigrodzkiej ziemi usiadt, Warszawa 22.04.1599; I. Corfus, Mihai Viteazul şi poloni, s. 242.

31 Kancelaria koronna nigdy nie przyznała mu tytułu książęcego. Zob. LL 27 s. 92-101. 
tuacji wyjątkowo cennym sojusznikiem dla niego stał się Jeremi Mohyła, pośrednictwo hospodara mołdawskiego umożliwiało Batoremu akceptację ze strony Porty Otomańskiej ${ }^{32}$. Bliska współpraca polityczna zaowocowała planami małżeńskimi córki Jeremiego (prawdopodobnie najstarszej Iriny, później Wiśniowieckiej) i przyrodniego brata Andrzeja Batorego — Jánosa Iffjú. Gwałtowny bieg wypadków, w których narzeczony Mohylanki poniósł śmierć, uniemożliwił ich realizację. Brzemienny w skutkach okazał się inny wspólny plan polityczny — plan usunięcia Michała z tronu wołoskiego i osadzenia na nim brata Jeremiego - Symeona ${ }^{33}$.

Wygląda na to, że strona polska nie była początkowo zainteresowana pomysłem wprowadzenia na tron wołoski Symeona Mohyły. Jan Zamoyski w liście do Jeremiego Mohyły pisał:

\begin{abstract}
Nie wiem jeśli J[eg]o Kr[ólewska] M[oś]ć oglądając się na obrazę p. p. [panów] chrześcijańskich raczy zechcieć o postanowieniu innego wojewody w Multaniech pomyśleć. Jednak radbym od W[aszej] $\mathrm{m}$ [iłości] wiedział, jeśliby miało do tego przyść, jeśli swemu Bratu czy komu tam inszemu życzyłbyś W[asza] m[iłość] tego tam województwa. Ja pewnie Pana Bratu W[aszej] m[iłości] i wszystkiemu domowi życzę wszystkiego dobrego. Ale na tem tam miejscu wolałbym widzieć kogo inszego. Bo usiadliby tam brat W[aszej] $\mathrm{m}$ [iłości], i sam by w ustawicznej prawie niewoli był, za uległością od W[aszej] m[iłości] i W[asza] m[iłość] także jakoby okowami pogańskimi upętałbyś się. Czekam [na] to odpisu W[aszej] m[iłości ${ }^{34}$.
\end{abstract}

Nie wiemy, co Jeremi Mohyła odpisał wówczas Zamoyskiemu, jednak króla przekonywał, że to Porta Otomańska ma zamiar zmienić hospodara na Wołoszczyźnie i chętnie widziałaby na tym miejscu jego brata Symeona ${ }^{35}$. Niewątpliwie hospodar mołdawski prowadził w tym zakresie własną politykę. $\mathrm{Z}$ drugiej strony ta polityka nie odbiegała daleko od planów polskich, wszak we wszystkich negocjacjach w sprawie utworzenia ligi antyosmańskiej polscy negocjatorzy żądali przyznania królowi polskiemu prawa do zwierzchnictwa nad obydwoma księstwami rumuńskimi ${ }^{36}$, a idea politycznego zjednoczenia Mołdawii, Wołoszczyzny i Siedmiogrodu pojawiała się wówczas faktycznie u wszystkich politycznych graczy, wszystkich równie wobec siebie wzajemnie nieszczerych.

Andrzej Batory już miesiąc po objęciu tronu siedmiogrodzkiego tytułował się Transilvaniae, Moldaviae, Valachiae Transalpinae princeps, o czym Jeremi Mohyła

32 E. Hurmuzaki, Documente, supl. 2, t. 1, s. 530 (Jeremi Mohyła do króla Zygmunta III, 02.06. 1599).

33 I. Horn, Andrzej Batory, Warszawa 2010, s. 250-251. Według węgierskiej badaczki Andrzej Batory nie był szczery w tych projektach i w rzeczywistości zamierzał osadzić na Wołoszczyźnie swego brata Stefana Batorego, a małżeństwo przyrodniego brata dawałoby mu perspektywę na Mołdawię.

34 Jan Zamoyski do Jeremiego Mohyły, b. m. i d.; AGAD, AZ 857, s. 1-4, brulion; I. Corfus, Documente... Secolul al XVI-lea, s. 136. Odpowiedź kanclerza była konsultowana z królem; idem, Mihai Viteazul şi poloni, s. 243 (P. Tylicki do J. Zamoyskiego, 22.04.1599).

35 AGAD, AZ 3028, s. 59-60, oryg. (Jeremi Mohyła do Zygmunta III, Suczawa, 27.08.1599).

36 A. Veress, Documente, t. 5, Bucureşti 1932, s. 42. 
albo nie wiedział, albo mimo wszystko grał w swoją grę ${ }^{37}$. Przede wszystkim bowiem z Siedmiogrodu pojawiły się naciski na Michała, by dobrowolnie ustąpił z tronu, co ten odczytał jednoznacznie, jako zamiar osadzenia tam Symeona Mohyły ${ }^{38}$. Nie była to do końca prawda, celem Batorego było podporządkowanie księstw rumuńskich obojętnie w jaki sposób. Gdy Michał okazał się skłonny do negocjacji i złożenia przysięgi na wierność Andrzejowi Batoremu, ten chętnie to przyjął i zwrócił się do Jeremiego Mohyły, by zaniechał nieprzyjaźni wobec hospodara wołoskiego ${ }^{39}$, tym samym szansa osadzenia Symeona na tronie w Târgovişte odsunęła się na czas bliżej nieokreślony.

Tymczasem Michał zdecydował się wykorzystać niepewną sytuację Andrzeja Batorego i podjął tajne negocjacje $\mathrm{z}$ cesarzem proponując wspólne uderzenie na Siedmiogród. Do konkretnego porozumienia w tej sprawie nie doszło, niemniej jednak Michał zdecydował się na atak. Pojawienie się w październiku wojsk wołoskich na południu kraju było dla Batorego zupełnym zaskoczeniem, a bitwa stoczona 28 tego miesiąca pod Sellenbergiem (rum. Şelimbăr) zakończyła się zupełną klęską jego wojsk. Co gorsza, kilka dni później uciekający z kraju Andrzej Batory został zamordowany przez Seklerów ${ }^{40}$.

Wiadomość o klęsce i śmierci Andrzeja Batorego wywołała panikę na dworze mołdawskim. Jeremi Mohyła nie miał najmniejszych wątpliwości, że kolejnym obiektem ataku będzie on sam ${ }^{41}$. Już w listopadzie 1599 roku zwracał się z prośbą do króla polskiego o zgodę na zaciąg żołnierzy. Król nie był jednak chętny do udzielenia takiego pozwolenia proponując, aby hospodar zwrócił się z prośbą do panów polskich $^{42}$. Mało tego, król w rozmowie z Piotrem Tylickim miał stwierdzić, że hospodar mógłby go o to nie pytać, co może świadczyć, że nie miał nic przeciw „samodzielnym" działaniom, o których w razie kłopotów mógłby powiedzieć, że nic nie wie i nie dawał na nie zgody. Jednak niebezpieczeństwo ze strony Michała potraktowano w Rzeczypospolitej bardzo poważnie tak, jakby dotyczyło ono ziem polskich. Podjęcie prewencyjnych działań zbrojnych było wprawdzie niemożliwe ze względu rozwijający się konflikt ze Szwecją, jak też niewskazane ze względów politycznych, jednak podjęto bardzo szeroką akcję dyplomatyczną na dworach europejskich wskazującą na zagrożenie hospodara mołdawskiego, znajdującego się, co podkreślano, pod

37 Ibidem, t. 5, s. 218.

38 Michał Waleczny do Jeremiego Mohyły, 20.12.1599; AGAD, AZ 3028, s. 64-66.

39 A. Veress, Documente, t. 5, s. 244-245 (Andrzej Batory do Jeremiego Mohyły, 02.08.1599).

40 Dokładna data śmierci jest wynikiem przypuszczeń. Najczęściej w literaturze śladem I. Szamosközy przyjmuje się datę 31 października 1599 r. Najprawdopodobniej jednak miało to miejsce kilka dni później, na pewno przed 10 listopada, kiedy głowę Andrzeja Batorego przywieziono Michałowi Walecznemu do Alba Iulii. L. Bazylow za najbardziej prawdopodobną uznał datę 9 listopada; L. Bazylow, Siedmiogród a Polska, s. 112. Biografka A. Batorego, Ildikó Horn nie podaje dokładnej daty.

41 E. Hurmuzaki, Documente, supl. 2, t. 1, s. 557 (Jeremi Mohyła do Jana Zamoyskiego, 10.11.1599).

42 I. Corfus, Mihai Viteazul şi poloni, s. 249-250 i 254-255 (P. Tylicki do Jana Zamoyskiego, b. d. i 30.11.1599). 
opieką króla polskiego ${ }^{43}$. Rozmiary tych działań wskazują na wagę, jaką przywiązywano wówczas do zachowania wpływów w Mołdawii. Nie zaniedbano w tym również i samego Michała, wysłano do niego jako posła dyplomatę, który już wcześniej wielokrotnie gościł na jego dworze, Andrzeja Taranowskiego ${ }^{44}$. Poseł polski spotkał się w marcu 1600 r. z Michałem Walecznym w Braszowie i wynegocjował tam układ, w myśl którego Michał, jako książę Wołoszczyzny, Mołdawii i Siedmiogrodu miałby zostać lennikiem króla polskiego ${ }^{45}$. W Polsce nie potraktowano jednak poważnie tej propozycji, wiedząc o doświadczeniach Andrzeja Batorego oraz podobnych propozycjach czynionych przez Michała cesarzowi i sułtanowi ${ }^{46}$. Niewątpliwie natomiast treść tego dokumentu musiała przekonać o zamiarze opanowania przez Michała Mołdawii.

Wraz z upływem czasu, po coraz częstszych informacjach o przygotowaniach Michała przeciw Mołdawii, król Zygmunt III coraz bardziej wyraźnie i jednoznacznie wypowiadał się na temat konieczności przygotowań wojskowych do obrony hospodara, wzywając szlachtę do gotowości oraz zezwalając hospodarowi na zaciąg żołnierzy. Mimo to, gdy w maju Michał wkroczył do Mołdawii przygotowania okazały się niedostateczne. Jeremi zdecydował się jednak stawić czoło przeciwnikowi wbrew wyraźnym instrukcjom ze strony króla i Zamoyskiego, że powinien się wycofać i czekać na zebranie się wojsk polskich. Skutek tego był fatalny, bitwa stoczona 17-18 maja pod Suczawą zakończyła się zupełną klęską hospodara mołdawskiego. Inna rzecz, że główną jej przyczyną okazało się niskie morale zaciągniętych Polaków i jeszcze niższe mołdawskich chłopów zmobilizowanych podobno w bardzo dużej liczbie 15000 żołnierzy ${ }^{47}$. Sprawdził się tutaj manewr Michała zastosowany wcześniej skutecznie w Siedmiogrodzie - wezwanie do buntu społecznego i obietnica zniesienia ciężarów feudalnych na 7 lat. W rezultacie ogromna armia Mohyły, złożona głównie z mołdawskich chłopów, rozpierzchła się i hospodar z niedobitkami musiał schronić się w Chocimiu, w którym został oblężony.

Co do konieczności udzielenia pomocy oblężonemu hospodarowi panowało w Polsce, poza nieliczną grupą popleczników Michała, powszechne przekonanie, był o tym przekonany król, Jan Zamoyski i większość senatorów ${ }^{48}$. Przygotowywaną wyprawę poprzedziło poselstwo Adriana Rembowskiego do sułtana Mehmeda III, któ-

43 AGAD LL 27, k. 146-177.

44 D. Bieńkowska, Michat Waleczny, Katowice 1975, passim.

45 AGAD LL 27, k. 155-156.

46 Tamże kopie tych listów.

47 I. Corfus, Mihai Viteazul şi poloni, s. 483-485 (anonimowy raport z Kamieńca, 18.05.1600); R. Heidenstein, Rerum Polonicarum ab excessu Sigismundi Augusti libri XII, Francofurti ad Moenum 1672, s. 350-352. Tłumaczenie polskie: R. Heidenstein, Dzieje Polski od śmierci Zygmunta Augusta do roku 1594 ksiąg XII, przekład Michał Gliszczyński, Opole 2015, s. 702-703.

48 Przekonanie to powiększały jeszcze pogłoski, że Michał zamierzał wkroczyć do Polski, a nawet sięgnąć po koronę; I. Corfus, Mihai Viteazul şi poloni, s. 296-299 (S. Żółkiewski do Piotra Tylickiego, 28.05.1600). 
rego celem było wyjaśnienie powodu i okoliczności polskiej interwencji zbrojnej w Mołdawii. W instrukcji dla posła, sporządzonej 6 lipca, a więc jeszcze przed wyprawą, czytamy:

... ten człowiek Michał tak się na Bogdańską Ziemię porwał i one posiadł, i że takowe pochwałki czyni, my go żadną miarą cierpieć nie chcemy i lubo też natenczas zatrudnienie królestwa naszego ojczystego dzieje się i posyłamy zaraz kanclerza i hetmana naszego z wojskiem, aby tam gdziebykolwiek Michał był szukał go. Około tej Ziemi Bogdańskiej wskazaliśmy przez pana halickiego i przez p. Herburta, że przodkowie naszy s. pamięci prze zabawy wojnami w Prusiech i z Moskwą nie mogąc ziemie tej opatrywać jako potrzeba niosła dozwolili hospodarowi tamecznemu, aby dwa tysiąca czerwonych złotych araczu z niej pozwolił na czas cesarzowi tureckiemu. Ale prawo do niej mamy i w zamieszaniu jej wojskiem naszym onę odratowaliśmy i na obronę jej nakłady czyniliśmy. Więc że od innych cesarza tureckiego dityi [!] tak odległa jest, przeto aby uważywszy to cesarz turecki pokazał nam chęć ustąpieniu jej, w czym iż odkazu doskonałego nie odnieśliśmy, a od roku do roku z kosztami wielkimi nie bez szkody państw naszych koronnych przychodzi nam bezpieczeństwo jej opatrywać, jako i teraz nie puszczamy. Przeto znowu żądamy, aby nam cesarz turecki chęć i przyjaźń swą w tej mierze oświadczył, żebyśmy prawo do tej ziemie mając, gdy do upadku nachyloną postanowiemy za pomocą Bożą w klubie swej zostali przy niej, gdyż stany koronne częstokroć się u niej pytają, przecz te nakłady od nas u niej się dzieją i co by za pożytek tak pilnego naszego o niej obmyśliwania był.

Przełożywszy to tak zasadzi się na tym staranie jako najpilnisze czyniąc, jakoby nam w wyratowaniu ziemie tej dobrze posłużył i czas jaki powlecze tego popierając. A kiedy już podobieństwa do wytargowania tego nie będzie baczył, ma pilność przyłożyć, jakoby wżdy namniej na tym stanęło, aby aracz, który teraz z tej ziemie bierze cesarz turecki pozwolił nam, gdyż obrona ziemie tej nie tylko ile ten aracz czyni, ale dobrze więcej co rok nas kosztuje. Pozwolenia tego araczu będzie się domagał na wieczne czasy i ma przy tej conclusiej odstąpienia trybutu ziemie wołoskiej i hołdu stać statecznie. Gdzieby więc wiedział, że upornie tego odmawia i broni cesarz, lepiej jużby rozerwać, aby się domawiał, żeby na czterdzieści, albo na trzydzieści lat był odstąpiony trybut, albo na koniec, na ilebykolwiek lat wytraktować mógł ${ }^{49}$.

Instrukcja ta znakomicie pokazuje, jak rozumiano wówczas na polskim dworze kwestię mołdawską, pokazuje też niezbicie i jednoznacznie, że wyprawa do Mołdawii podjęta w 1600 roku była rezultatem polityki państwa, a nie prywatnym przedsięwzięciem magnackim, czy półprywatnym działaniem Jana Zamoyskiego ${ }^{50}$. Inna rzecz, że ze względu na obiektywne trudności w zebraniu wojska, dominującą rolę w jego składzie odegrały poczty prywatne Potockich, Żółkiewskich, Daniłowiczów, Chodkiewiczów, Wiśniowieckich, Sobieskich.

Interwencja zbrojna rozpoczęta 4 września zakończyła się pełnym sukcesem. Przyniosła ona restaurację rządów Jeremiego Mohyły w Mołdawii, a następnie pokonanie Michała pod Bukowem w jego rodzinnej Wołoszczyźnie 20 października ${ }^{51}$.

49 AGAD LL 27, k. 160v-161v.

50 Jasny wykład w tej sprawie zob. też R. Heidenstein, Dzieje Polski, s. 708.

51 R. Heidenstein, Rerum Polonicarum ab excessu Sigismundi Augusti, s. 352-362; D. Skorupa, Bitwa pod Bukovem 20 października 1600 r., [w:] Staropolska sztuka wojenna XVI-XVII wieku. Prace ofiarowane prof. Jaremie Maciszewskiemu, red. M. Nagielski, Warszawa 2002, s. 17-43; idem, Stosunki polsko-tatarskie, s. 94. 
Dalszą konsekwencją tego było osadzenie Symeona Mohyły w stolicy Wołoszczyzny Târgovişte, początkowo zresztą za porozumieniem ze stacjonującymi tam dowódcami osmańskimi ${ }^{52}$.

Sprawa osadzenia Symeona Mohyły na tronie wołoskim wymaga dogłębnych badań. Wygląda na to, że rację mają ci badacze, którzy łączą je z poparciem osmańskim, a przynajmniej przekonaniem strony polskiej, że takie poparcie istnieje. Nie mamy jednak pełnej jasności jak to wyglądało w rzeczywistości, polityka osmańska w tej sprawie też nie rysuje się jednoznacznie.

Po wycofaniu się głównych sił polskich z Janem Zamoyskim na czele, pozostawiono Symeonowi Mohyle część chorągwi polskich z obowiązkiem ich utrzymania ${ }^{53}$. Zapewne dzięki temu 25 listopada udało się nowemu hospodarowi wołoskiemu jeszcze raz pokonać Michała i niedobitki jego wojsk pod miastem Argeş ${ }^{54}$. Symeon, jako Mołdawianin, nie miał jednak szerokiego oparcia wśród wołoskich rodów bojarskich, większość z nich otwarcie nastawiona była wrogo. Wrogom Symeona przewodziła rodzina Buzescu, której trzej przedstawiciele Radu, Preda i Stroe stanęli na czele powstania, doprowadzili do usunięcia go z Târgovişte, a sami przejęli władzę w imieniu przebywającego w Siedmiogrodzie Michała Walecznego. W czerwcu 1601 r. Mohyła został wyparty z Wołoszczyzny na granicę mołdawską, skąd zwrócił się do króla polskiego z prośbą o pomoc. Zygmunt III wysłał mu wówczas na pomoc Jana Potockiego z wojskiem ${ }^{55}$.

W międzyczasie jednak nastąpiły duże zmiany sytuacji ogólnej; 9 sierpnia zamordowany został Michał Waleczny, w związku z czym sułtan mianował dla Wołoszczyzny nowego hospodara Radu Mihnię, który przy pomocy osmańskiej wkroczył na Wołoszczyznę. Z kolei zwolennicy antytureckiej i procesarskiej polityki zamordowanego Michała wybrali na hospodara miejscowego bojara Radu Şerbana ${ }^{56}$. Walka między nimi toczyła się przez następne miesiące ze zmiennym szczęściem. W listopadzie Potocki ponownie wprowadził Symeona Mohyłę na tron wołoski, starając się przekonać urzędników tureckich do jego akceptacji. Do agi janczarów, stacjonującego w Giurgiu pisał on: $1600])$.

52 I. Corfus, Documente... Secolul al XVI-lea, s. 429 (Jan Potocki do Ejuba paszy, b. d. [listopad

53 Conditie na ktore przysięgali Hospodarowie oba Hieronim Wotoski y Symeon Mohiła Brat Hieronimow Hospodar Multański teraźniejszy; Biblioteka Jagiellońska, Kraków, Rkps 102, s. 13; E. Hurmuzaki, Documente, supl.1, t. 1, s. 642-643. Tu także opis wyprawy - s. 638-642.

54 E. Hurmuzaki, Documente, supl. 2, t. 1, s. 651 (Jeremi Mohyła do J. Zamoyskiego, 10.12.1600).

55 J. Otwinowski, Powodzenia niebezpiecznego ale szczęśliwego wojska JKM przy JM Panu Staroście Kamienieckim w Multaniech opisanie prawdziwe przez Jarosza Otwinowskiego roku 1600, Kraków 1601.

56 Warto jednak zwrócić uwagę, że w popularnym opracowaniu Z. Spieralskiego, Awantury motdawskie, s. 155 znajduje się błąd. Autor ewidentnie pomylił narzucanego przez sułtana Radu Mihnię, syna Mihnii Poturczeńca z jednoznacznie antytureckim Radu Şerbanem. 
że jest pod obroną Simeon wojewoda multański najjaśniejszego króla polskiego pana mojego miłościwego z pierwszego przyprowadzenia na państwo i wojsko tedy jego królewskiej mości pana mojego miłościwego ustąpienia stąd nie dopuści, gdyż o tym żadnego rozkazania nie ma od jego królewskiej mości, ale gdzie cesarz jego mość z najjaśniejszym królem polskim o tym się porozumie, a rozkazanie jego królewskiej mości przystąpi żebychmy ustąpili, tej godziny ustąpimy"... ${ }^{57}$

Polityka polska wobec Wołoszczyzny w tym czasie to odrębny temat, którego nie chciałabym teraz szerzej poruszać. Na pierwszy rzut oka wygląda na dość podobną do tej, jaką stosowano wobec Mołdawii, były to jednak pozory. W odróżnieniu od Mołdawii, Wołoszczyzna nigdy nie była traktowana tak do końca jako swój kraj. Brakowało wspólnej tradycji związków państwowych i odpowiednio silnego oparcia politycznego w tym kraju. Nie sprzyjał też dobrej współpracy głęboki konflikt, jaki wybuchł między Symeonem Mohyłą a polskimi najemnikami na tle zapłaty żołdu. Żołnierze polscy pozostawieni Symeonowi Mohyle masowo opuszczali służbę. Inna rzecz, że nie był to najprawdopodobniej zbyt wartościowy element. W związku z konfliktem w tej sprawie Symeon wysłał do króla posłów kluczara Wasila i wisternika Woika z wyjaśnieniem ${ }^{58}$. Wyraźnie jednak po wyparciu Symeona z Wołoszczyzny jesienią 1602 roku aktywność polska w udzielaniu mu pomocy spadła. Sprawa ta wprawdzie pojawiła się na sejmie w 1603 roku, w którym uczestniczyli wspólni posłowie Jeremiego i Symeona Mohyłów. Na rzecz wznowienia walki o Wołoszczyznę, jako o wielce wartościowy i bogaty kraj wypowiadał się Marek Sobieski, ten sam, który już wcześniej domagał się od obydwu hospodarów partycypacji w kosztach utrzymania wojska w postaci stałego trybutu ${ }^{59}$. Obrady sejmu przytłoczyły jednak inne sprawy, przede wszystkim wojna ze Szwecją ${ }^{60}$.

Imperium Osmańskie, prowadzące wówczas ciężką wojnę z cesarzem, nie było zainteresowane rozpoczęciem konfliktu, dlatego milcząco nadal godziło się na wpływy polskie w Mołdawii, nie godziło się jednak na rozszerzenie tych wpływów na Wołoszczyznę.

Taka sytuacja utrzymała się do śmierci Jeremiego Mohyły 30 czerwca/10 lipca 1606 roku. Wobec faktu, że najstarszy spośród trzech synów Jeremiego, Konstanty, liczył dopiero ok. 10 lat, hospodarem w Mołdawii został brat Jeremiego — Symeon. Odsunął on od władzy wdowę po Jeremim, Elżbietę, która opuściła kraj i zamieszkała z dziećmi w znajdującej się na terenie Rzeczypospolitej majętności Uście. Natychmiast po śmierci Jeremiego Zygmunt III pisał do sułtana Ahmeda I o mianowanie hospodarem członka rodziny Jeremiego, spodziewając się mianowania jego sy-

57 I. Corfus, Documente privitoare la istoria românilor culese din arhivele polone. Secolul al XVII-lea, Bucureşti 1983, s. 5.

58 Niedatowana instrukcja od Symeona: AGAD LL 26, k. 28-30; Niedatowana instrukcja od metropolity i bojarów — tamże, k. 30v.-31. W instrukcjach tych bardzo dokładny opis wydarzeń. Zob. też listy i dziennik Ławryna Piaseczyńskiego w tej sprawie; I. Corfus, Documente... Secolul al XVII-lea, s. 33-38.

59 AGAD, AZ, 3028, p. 167-169.

60 B. Janiszewska-Mincer, Rzeczpospolita Polska w latach 1600-1603 (Narastanie konfliktu między Zygmuntem III Waza a stanami), Bydgoszcz 1984, s. 112. 
na ${ }^{61}$. Porta Otomańska zaakceptowała jednak Symeona, co wywołało w Polsce pewną konsternację.

Należy zwrócić uwagę, że od 1598 roku w państwie osmańskim całkowicie zmieniła się ekipa rządząca. Mehmeda III, jeszcze w 1603 roku zastąpił nieletni Ahmed I, za którego rządów już na samym początku zmieniło się kilku wielkich wezyrów. Przede wszystkim jednak w 1606 roku pokojem w Zsitvátörök zakończyła się 15-letnia wojna Imperium Osmańskiego z Cesarstwem. Umocniło to znacznie pozycję osmańską i musiało wpłynąć na usztywnienie stanowiska wobec Mołdawii i Polski.

Rzeczpospolita nie mogła sobie pozwolić na pogorszenie relacji z państwem osmańskim dlatego też na pogwałcenie porozumienia z 1598 roku, gwarantującego sukcesję synowi Jeremiego, zareagowała dyplomatycznie. W instrukcji dla Mikołaja Daniłowicza wysłanego do Porty latem 1607 roku znalazło się zalecenie:

Ma też o to poseł nasz czynić pilne staranie, aby Siemion, któremu prawo z dawna służy i do wojewodztwa multańskiego, gdy się okazja poda do tego województwa był przywrócony i przy nim w pokoju do żywota zachowany, co jednak poseł nasz tak skrycie ma traktować, żeby jakokolwiek Simion [nie mógł] postrzec ${ }^{62}$.

W układzie zawartym 15 lipca nie znalazły się jednak w ogóle żadne zapisy zabezpieczające panowanie dla Mohyłów, znalazło się natomiast podkreślenie zwierzchności sułtana nad Mołdawią i Tatarami, co wywołało niezadowolenie króla, który nawet zamyślał o renegocjacji układu ${ }^{63}$.

Tymczasem w krótkim czasie, już 24 września 1607 roku zmarł również Symeon. Znany kronikarz mołdawski, żonaty z wnuczką Symeona, Miron Costin, rozpowszechnił twierdzenie, że został on otruty przez dążącą do władzy wdowę po Jeremim - Elżbietę Mohyłową ${ }^{64}$. Wydaje się to jednak mało prawdopodobne zważywszy że 1. nie było jej wtedy w Mołdawii, 2. nie zabezpieczyła ona bynajmniej sukcesji dla swojego syna, lecz dopiero musiała o nią walczyć, bowiem tron mołdawski przejął natychmiast najstarszy syn Symeona - Michał, mało tego, zdążył zapewnić sobie poparcie sultana ${ }^{65}$.

Po śmierci Symeona król Zygmunt III jednoznacznie poparł na tron hospodarski Konstantego Mohyłę, co znalazło swój wyraz w instrukcji dla posła do Porty Abrama Krzewskiego. Pisał on tak:

Jeśliby Michał jeszcze zostawał przy nadziei państwa, a przyszłoby do tego, żeby przez praesidia jego jechać musiał, będzie mu i matce jego perswadował, aby uporu odstąpili i domu swego, który

61 I. Corfus, Documente... Secolul al XVI-lea, s. 143-144.

62 Ibidem, s. 146.

63 D. Kołodziejczyk, Ottoman-Polish diplomatic relations, s. 329-344. Reakcja króla zob. AGAD, Archiwum Publiczne Potockich, 7, t. 1, s. 203; D. Skorupa, Stosunki polsko-tatarskie, s. 141 (Zygmunt III do S. Lubomirskiego, 16.10.1607).

${ }_{64}$ M. Costin, Latopis, s. 117.

65 A. Veress, Documente, t. 8, s. 30-32 (Mustafa pasza do Zygmunta III, wrzesień 1607). 
łaską jego krolewskiej mości do tej godności przyszedł, niezgodą do zguby nie przywodzili. Tak jednak będzie z nim traktował, aby mu jako żadnego prawa na hospodarstwo nie przyznawał, tak też nadzieje łaski jego krolewskiej mości nie umykał ${ }^{66}$.

Niewątpliwie więc wyprawa podjęta w grudniu 1607 roku pod wodzą Stefana Potockiego i Michała Wiśniowieckiego w celu osadzenia na tronie mołdawskim Konstantego Mohyły odbyła się za pełną aprobatą króla, który potwierdzał, że realizowała ona dawno przyznane Konstantemu prawo do tronu ${ }^{67}$. Zakończyła się ona pełnym sukcesem, po zwycięstwie w bitwie pod Stepanowcami (Stefaneşti) nad wojskami Michała Mohyły dowodzonymi przez Vasila Stroicia w dniu 19 grudnia osadzono Konstantego na tronie w Jassach ${ }^{68}$. Abram Krzewski został wysłany do sułtana specjalnie w celu uzyskania jego akceptacji dla Konstantego ${ }^{69}$, co się co się dość łatwo udało, zapewne ze względu na rychłą śmierć Michała na Wołoszczyźnie. Sułtan Ahmed I w liście do króla Zygmunta III z lutego 1608 roku, podkreślił swoje wyłączne prawo do mianowania hospodara w Mołdawii, ale ostatecznie zatwierdził Konstantego ${ }^{70}$. W istocie Porta przez dłuższy czas faktycznie tolerowała fakt, że przez cały okres panowania Konstantego na jego żołdzie znajdowały się oddziały polskie.

Niestety sytuacja w regionie (naciski ze strony księcia siedmiogrodzkiego Gábora Batorego, antyosmańskiego hospodara wołoskiego Radu Şerbana), problemy finansowe i konflikty wewnętrzne przerosły młodego hospodara. W listopadzie 1611 roku został on odwołany przez sułtana i wezwany do przybycia do Porty, a na jego miejsce mianowany został syn znanego wroga Polski - Stefan Tomşa. Wbrew rozkazowi Konstanty nie udał się do Stambułu, lecz do Polski.

Dla króla polskiego odwołanie Konstantego i mianowanie wyraźnie wrogiego Tomşy stanowiło jawne pogwałcenie układów. W marcu 1612 r. pisał do senatorów:

Na ziemię wołoską nastąpił z prędka z tureckiego dworu człek, ktory się Tomszynem synem zowie. Ustąpić przyszło Constantemu synowi Hieremy Mohiły dobrze nam zasłużonego, który był pod opieką naszą i Rzptej. Stało się to przeciw upewnieniu, które nam od cesarza tureckiego posłaniec nasz urodzony Samuel Targowski przyniósł, że miał być ten tam Constantin na tem tam państwie zachowany ${ }^{71}$.

$\mathrm{Z}$ drugiej strony monarcha zdawał sobie jednak sprawę $\mathrm{z}$ tego, że odwołanie Konstantego nie nastąpiło bez powodu. Niewybaczalnym błędem były zaległości

66 I. Corfus, Documente privitoare la istoria românilor culese din arhivele polone. Secolele al XVI-lea şi al XVII-lea, Bucureşti 2001, s. 149.

67 I. Corfus, Documente... Secolul al XVII-lea, s. 46-48.

68 Ibidem (anonimowy dziennik wyprawy).

${ }^{69}$ Krzewski przygotowywany był do poselstwa jeszcze w grudniu 1607 r., wyruszył jednak dopiero ok. 18 stycznia, gdy wiadomy był już skutek wyprawy; I. Corfus, Documente... Secolele al XVI-lea, s. 159.

70 Ibidem, s. 159-163, tu: s. 160 (Ahmed I do Zygmunta III).

71 AGAD, LL 28, k. 29; tu: 292v-293. 
w opłacie haraczu, a także otwarte udzielenie azylu i pomocy Radu Şerbanowi ${ }^{72}$. Rządzący państwem osmańskim sułtan Ahmed I i wielki wezyr Nasuh pasza nie dążyli do konfliktu z królem polskim, dlatego w prywatnych listach do niego wyjaśniali bardzo konkretne przyczyny odwołania Konstantego. W listach tych znalazł się jednak groźny element w postaci żądania wydania Konstantego i jego zwolenników ${ }^{73}$. Zygmunt III uznał, że możliwe będzie cofnięcie decyzji sułtana o odwołaniu Konstantego, jeśli zapłacone zostaną zaległe należności i bakszysz dla urzędników osmańskich. Aby przygotować grunt w tej sprawie wysłał do Stambułu posła Grzegorza Kochańskiego ${ }^{74}$. Poseł wysłany został w kwietniu 1612 r., w czerwcu był już w Stambule, gdzie uzyskał audiencję u sułtana i wielkiego wezyra, jednak bez pozytywnego rezultatu ${ }^{75}$.

Z drugiej strony król zalecił Stefanowi Potockiemu zbiórkę pieniędzy na zapłacenie przez Konstantego zaległego haraczu i przygotowanie wyprawy wprowadzającej go z powrotem na tron. Pieniądze te miały być zebrane przede wszystkim od byłych urzędników mołdawskich, którzy uciekli wraz z Konstantym do Polski i w większości jako indygeni polscy mieli tu także swoje majątki. W instrukcji dla swojego wysłannika Wojciecha Miaskowskiego król pisał:

Ale gdzieby ociętni [!] byli ostatnią wolą naszą otworzyć im przydzie, aby oni z depozytów ich, gdzie by się kolwiek znalazły, tak tę rzecz opatrzyli, jakoby haracz Turkowi był jako najprędzej odesłany i Konstanty jako najpotężniej tamtego intruza sparł i posiłki wojska kwarcianego na granicach Rzeczypospolitej stanęly ich dostatkami, ponieważ ich złe rady w tę mieszaninę i pana ich prowincyją tamtę i granicę państw naszych wprowadzili ${ }^{76}$.

Jak widać król pierwotnie zamierzał zmobilizować Mołdawian do podjęcia działań w imieniu Konstantego, rozwiązać drogą dyplomatyczną i finansową konflikt z Turkami i wysłać młodego hospodara z powrotem do Mołdawii z siłami, które pozwolą mu pokonać przeciwnika. Do przygotowań tych włączyła się również miejscowa szlachta. Po latach Wojciech Miaskowski, pisał co następuje:

... z rozkazania królewskiego zjeżdżałem w tymże roku do Lwowa i na to wojsko i niefortunną ekspedycyją piniądze dawałem z konstytucyjej panów wołoskich posłany. Byłem potem od króla J Mci dla zatrzymania wojska w Podolu, ale już z niem był przeszedł Dniestr i Prut pan starosta feliński, wyżej mianowany do Wołoch, ani się chciał wrócić nazad do Korony sic urgente et impellente fato, które i pana Golskiego, wojewodę ruskiego, z frasunku wielkiego w kilka dni w grób wpędziło

72 AGAD, LL 28, k. 371v-373 (Ahmed I do Zygmunta III, marzec 1612); I. Corfus, Documente... Secolul al XVII-lea, s. 81-82.

73 AGAD, LL 28, k. 369-370, 371-373; I. Corfus, Documente... Secolul al XVII-lea, s. 75-83.

74 AGAD, LL 28, k. 373-376 (Zygmunt III do Ahmeda III, czerwiec 1612).

75 I. Corfus, Documente... Secolele al XVI-lea, s. 187-188 (Grzegorz Kochański do Stefana Potockiego).

76 Ibidem, s. 181-183 (instrukcja królewska dla Wojciecha Miaskowskiego, 05.04.1612). 
w Kamieńcu z tej przyczyny, że Potockiego jako szwagra swego w tej nieszczęsnej potrzebie posiłkować nie mógł, stanąwszy nad Dniestrem ex opposito Chocimia ${ }^{77}$.

Jak więc widzimy, król początkowo popierał przygotowania, do udziału w wyprawie wzywał również niechętny tej linii Mohyłów hetman Stanisław Żółkiewski ${ }^{78}$. W ostatnim momencie dopiero król zmienił zdanie i próbował zatrzymać Potockiego, było już jednak za późno. Tłumaczy to pozornie sprzeczne listy króla w tej sprawie ${ }^{79}$.

Dowodzona przez Stefana Potockiego wyprawa zbrojna po początkowych sukcesach zakończyła się jednak tragicznie. Dowodzone przez Potockiego wojska młodego hospodara zostały pobite w trzydniowej bitwie $11-13$ lipca 1612 r. nad Prutem ${ }^{80} \mathrm{w}$ okolicy Sasowego Rogu i, poza tymi, którzy dostali się do niewoli tatarskiej lub Tomşy, wycięte w pień nie tylko przez Turków i Tatarów, lecz także przez miejscowych chłopów ${ }^{81}$.

Konstanty został wzięty do niewoli pewnego Tatara, który zamierzał zawieźć do samego chana. W czasie podróży na Krym Dnieprem rozpętała się burza, przy silnym wietrze łódź wywróciła się i wszyscy jej pasażerowie włącznie z młodym hospodarem utonęli. Bojarzy mołdawscy, którzy znajdowali się przy Konstantym, w liczbie 36, dostali się do niewoli Tomşy i zostali straceni. Sam Potocki również dostał się do

77 Poselstwo Wojciecha Miaskowskiego do Turcji w 1640 r., opr. A. Przyboś, Warszawa-Kraków 1985, s. 46-47.

78 Listy i odezwy na ten temat: Pisma Stanisława Żółkiewskiego kanclerza koronnego i hetmana, Lwów 1861, s. 411-416.

79 Na te sprzeczności zwrócił uwagę D. Skorupa, Stosunki polsko-tatarskie, s. 168-169.

80 Datacja bitwy jest dyskusyjna. Powszechnie w polskiej literaturze przyjmuje się datę 19 lipca. Datę 11-13 lipca zaproponował rumuński badacz Constantin Rezachevici, Bătalia de la , Cornul lui Sas ” (3/13 iulie 1612). Reconstruire, ,Studii şi Materiale de Istorie Militară” 1976, t. 9, s. 59-70; idem, Două rectificări cronologice privind istoria Moldovei în veacul al XVII-lea, „Studii. Revista de istorie” 1972 , t. 25, nr 2, s. 311-314. Podstawą ustalenia tej datacji jest list patrycjatu miejskiego w siedmiogrodzkiej Bystrzycy do Gabriela Batorego z dnia 19 lipca właśnie. W tym dniu w znajdującej się w innym państwie za górami Bystrzycy wiedziano już o klęsce Konstantego Mohyły, a nawet ją opisano: ...der Stephan Vayda sambt den Murzesten, dem Landtvolk und einer Anzahl Taittem, zwo Meil 'Wegs underhalb dem Markt Jaz mit dem Constantin und seinen polnischen Schwägem getroffen, drey Tag von Mittwochen bis auf den Freytag mit einander gestritten und entlich die Polen geschlagen worden. Der Constantin sambt etlichen bey sich habenden Boiern, dem Baliczel, Stroitzel, Boul Vizternik, des Ureke Sohn und des Constantini jungster polnischer Schwager sein lebendig gefangen worden, und haben die Turggen, welche gleichwol bey dem Treffen mit gewesen, auf der flüchtigen Polen Fürschlag in Polen -eingefallen. Was weiter verlauft, berichten wir hienach; A. Veress, Documente, t. 8, s. 265. Jak widać mieszczanie bystrzyccy mieli trochę niedokładne informacje na temat losów uczestników bitwy (na temat tego, co stało się z Konstantym nie wiedziano przecież przez wiele miesięcy), to jednak informacje na temat czasu bitwy (od środy do piątku) należy uznać za właściwe. Dlatego, mimo że dodatkowe argumenty za datą 19 lipca podał ostatnio D. Skorupa, Stosunki polsko-tatarskie, s. 171, przekonuje mnie nadal teza C. Rezachevicia.

81 Całe pozostałe wojsko polskie popadło $w$ niewolę tatarska $i$ w większości potopiło się $w$ Prucie. Powiadaja, że ledwo kto uszedt, że jeśli ktoś przepłynąt Prut, tąki za Prutem pełne były chłopów i koszów tatarskich, ci wszystkich chwytali i prowadzili do wojewody Tomszy, najwięcej jednak zabili chtopi; M. Costin, Latopis, s. 120. 
niewoli Tomşy, a ten z kolei odesłał go do Stambułu do sułtana, skąd wyszedł później za okupem.

Po klęsce król wyparł się jakiegokolwiek swojego udziału w przygotowaniu wyprawy, a na uczestników posypały się gromy za prywatę.

Strona polska nie pogodziła się z panowaniem Tomşy w Mołdawii i praktycznie w każdym poselstwie i w każdym liście do sułtana znajdowały się skargi na hospodara i żądanie jego zmiany — bez skutku. W 1615 roku pojawiła się nowa sposobność do podjęcia działań w tej sprawie, gdyż jesienią tego roku nastąpił poważny konflikt panującego w Mołdawii hospodara z bojarami, którzy próbowali odsunąć go od władzy zamykając $w$ areszcie domowym. Tomşy udało się wprawdzie uwolnić $\mathrm{i}$ wbić na pale część buntowników, jednak część z nich zdołała uciec do Polski i poprosić o po$\operatorname{moc}^{82}$. Jeśli Mohyłowie mieliby kiedykolwiek powrócić na tron, to mogło się wydawać, że nie było lepszej sytuacji. Tomşa faktycznie nie panował nad krajem, a Turcja nie mianowała jeszcze nowego hospodara, ponadto zaangażowana była w wojnę ze swym odwiecznym wrogiem - Persją i wstrząsana licznymi wystąpieniami społecznymi (celali). W dodatku panowie polscy byli przygotowani do wojny, gdyż spodziewali się najazdu tatarskiego, a Tatarów z kolei zatrzymały rozlane wody dolnego Dniestru ${ }^{83}$.

Niestety jednak w tej sprzyjającej sytuacji natychmiast dała o sobie znać rywalizacja dwóch gałęzi Mohyłów. Niektóre informacje z tego czasu zdają się wskazywać, że jednocześnie obydwie szwagierki Elżbieta, wdowa po Jeremim, jak i Małgorzata, wdowa po Symeonie, poczęły zbierać ludzi w celu wkroczenia do Mołdawii. Na rzecz syna Symeona, Gabriela, zbierał osobno zbrojnych sam hetman Żółkiewski lub jego syn $^{84}$, przelicytowali go jednak szybko książęta Michał Wiśniowiecki i Samuel Korecki działający na rzecz kilkunastoletniego wówczas syna Jeremiego - Aleksandra ${ }^{85}$.

82 A. Veress, Documente, t. 9, s. 59 (G. Bethlen do F. Daróczy, Mediaș, 10.10.1615); ibidem, t. 9, s. 61 (G. Bethlen do A. Dóczy, Alba Iulia, 20.11.1615); Joppecourt Charles de, Histoire sommaire des choses plus memorables advenves aux derniers troubles de Moldavie ou sonr descrites plusieurs batailles gaignees tant par les princes polonois, que par les Turcs et Tartares, Paris 1620, wyd. I. Barret, [w:] Papiu-Illarian Alexandru, Tesauru de monumente istorice, t. 2, Bucureşti 1863, s. 26-27.

83 A. Veress, Documente, t. 9, s. 61 (G. Bethlen do A. Dóczy, Alba Iulia, 20.11.1615); ibidem, t. 9, s. 62 (G. Bethlen do A. Dóczy, Alba Iulia, 21.11.1615).

84 Ibidem, t. 9, s. 58 (Simon Péchy do George Thurzó, Mediaş, 02.11.1615). Autor listu osobę, która prowadziła mobilizację na rzecz syna Symeona (mylnie nazywa go Aleksandrem), określa mianem Sulkowski, co Węgrzy czytali Szulkowski. W późniejszych listach identycznie określa się naczelnego wodza polskiego wojska, niewątpliwie więc, że chodzi tu o Żółkiewskiego. O przygotowaniach Gabriela Mohyły do objęcia tronu mołdawskiego świadczy też list Stanisława Tarnowskiego do Zbigniewa Ossolińskiego z 10 lutego 1616 r., w którym pisze: Hawriłowka się napieraja i swem osobnem obozem leża; E. Hurmuzaki, Documente, supl. 2, t. 2, Bucureşti 1895, s. 391. O przygotowaniach wojskowych na rzecz syna Symeona Mohyły donoszono jeszcze w 1614 r.; A. Veress, Documente, t. 9, s. 10-11.

85 Nieprzychylni (w tym Stanisław Żółkiewski - Pisma Stanisława Żółkiewskiego kanclerza koronnego i hetmana, Lwów 1861, s. 243) określali go jako „dziecię lat dziesięciu czy jedenastu”. W rzeczywistości musiał liczyć co najmniej 13 lat. Jego ojciec zmarł w 1606 roku, a Aleksander miał jeszcze czworo młodszego rodzeństwa. 
W listopadzie 1615 r. książęta wyruszyli na podbój Mołdawii ${ }^{86}$. W dniu 23 listopada doszło do decydującego starcia z Tomşą i towarzyszącymi mu Tatarami pod Tătăreni-Tăutești w pobliżu Jass. Wojska Tomşy zostały rozbite, a on sam musiał ratować się ucieczką ${ }^{87}$. Zwycięzcy wkroczyli do stolicy i posadzili na tronie hospodarskim Aleksandra Mohyłę.

Sytuacja polityczna wewnątrz państwa mołdawskiego była jednak wówczas zdecydowanie odmienna od tej z roku 1595, 1600, 1607, a nawet 1612. Po klęsce pod Sasowym Rogiem w wyniku represji Stefana Tomşy została fizycznie wyeliminowana większość bojarów powiązanych rodzinnie z Mohyłami. Pozostała część dawnej promohylańskiej partii bojarskiej bądź podzieliła się sympatiami między Aleksandra i Gabriela, bądź też gotowa była pogodzić się z rządami każdego hospodara. Z tego względu Aleksander i jego matka nie mogli liczyć na szerokie poparcie w kraju, przeciwnie rychło ujawniła się silna opozycja. Rezultatem jej działań było zamordowanie (otrucie w komunii) Michała Wiśniowieckiego na początku stycznia 1616 r. Po śmierci Wiśniowieckiego siły interwencyjne uległy osłabieniu, nadal jednak utrzymywał się ze swym wojskiem Samuel Korecki, który w kwietniu 1616 r. ożenił się z siostrą osadzonego przez siebie na tronie Aleksandra - Katarzyną ${ }^{88}$.

Nie chcąc wchodzić w szczegóły wyprawy, wypada stwierdzić, że ciągnęła się ona ponad 10 miesięcy i nie pozostawała bez szans utrzymując Aleksandra na tronie w Jassach. Dopiero na początku sierpnia 1616 r. Samuel Korecki z Aleksandrem Mohyłą, żoną i teściową zostali zaatakowani przez wojska tureckie Iskendera paszy, wołoskie Radu Mihnii, siedmiogrodzkie Gabora Bethlena oraz Tatarów ${ }^{89}$. Do decydującej bitwy doszło w połowie drogi między Cotnari a Botoșani, co później Miron Costin zidentyfikował, jako Dracșani w okręgu Hârlau ${ }^{90}$. W polskiej literaturze hi-

86 Według Joppecourta książęta mieli przekroczyć granicę 16 października 1616 [!] roku. Autor ten jednak podaje często dość niedokładne dane, w tym ustawicznie myli datę roczną, prawdopodobnie spisywał wspomnienia z pamięci. W korespondencji Siedmiogrodzian pierwsze informacje o wkroczeniu Polaków pojawiają się dopiero w końcu listopada.

87 Na 23 listopada datował tę bitwę Michał Wiśniowiecki, komentując na bieżąco jej przebieg; BK 324, k. 187 v. (M. Wiśniowiecki do E. Mohyłowej, 24.11.1615). Podobnie też K. Szábó, Bethlen Gábor fejedelem politikai levelezése, Magyar Történelmi Tár 1880, s. 486-487 (M. Wiśniowiecki do Gábora Bethlena, Jassy, 09.12.1615) i ibidem, s. 487-488 (Samuel Korecki do Gabora Bethlena, Jassy 10.12.1615). Powszechnie w literaturze historycznej datuje się tę bitwę na 22 listopada; N. Iorga, Doamna lui Ieremia vodă, București 1910, s. 24 (1042); A. Golimaș, Lupta decisiva de la Tătăreni și la capitularea darabanilor deasupra Tăuteștilor, Iași 1935; N. Iorga, Istoria românilor, t. 5, wyd. 2, București 1998, s. 401. Niekiedy pojawia się też data 21 listopada; V. Ciobanu, Idei politice la Nestor Ureche: determinării, surse, motivaţii, Anuarul Institutului de istorie „A. D. Xenopol” 1992, t. 29, s. 300.

88 Szerzej na temat całej wyprawy: I. Czamańska, Kampania mołdawska Samuela Koreckiego 1615-1616, [w:] Si vis pacem, para bellum. Bezpieczeństwo i polityka Polski. Księga jubileuszowa ofiarowana prof. Tadeuszowi Dubickiemu, red. R. Majzner, Częstochowa-Włocławek 2013, s. 125-140.

89 Starcie najczęściej datowane jest na 13 sierpnia (3 starego stylu), Joppecourt datuje je dopiero na 23 sierpnia. Jednak niektórzy jego uczestnicy, jak Tyszkiewicz, już 5 sierpnia dotarli do Kamieńca Podolskiego, niewątpliwie bitwa musiała mieć miejsce 3 sierpnia.

90 M. Costin, Latopis, s. 124-125. Obecnie miejscowość ta znajduje się w okręgu Botoşani. 
storycznej, śladem Zdzisława Spieralskiego, miejsce bitwy identyfikowane jest często mylnie z Sasowym Rogiem nad Prutem, co jest dużym błędem ponieważ miejsca te dzieli znaczna odległość ok. $100 \mathrm{~km}$. Przewaga nieprzyjaciela była ogromna i ostatecznie Elżbieta Mohyłowa z synami Aleksandrem i Bogdanem oraz Samuel Korecki i jego małżonka dostali się do niewoli tureckiej lub tatarskiej (Katarzyna MohylankaKorecka). Z punktu widzenia militarnego jednym z głównych powodów niepowodzenia tej wyprawy było całkowite odcięcie przez hetmana Stanisława Żółkiewskiego możliwości uzupełniania ludzi i zapasów.

Niewątpliwie ta wyprawa wygląda na zupełnie nie powiązaną z polityką królewską i polityką państwową. Tym razem król Zygmunt III oficjalnie surowo zakazał udziału w wyprawie na rzecz Aleksandra, tak było jednak tylko oficjalnie. Przyjaciele zapewniali ks. Samuela Koreckiego o przychylności króla do jego działań, przychylny wydawał się także kanclerz, Feliks Kryski ${ }^{11}$, ogólny klimat był jednak niekorzystny i nikt nie odważył się powiedzieć tego głośno. Ten sam kanclerz, który w listach wyrażał swe poparcie, na sejmie grzmiał przeciw „swawolnemu wejściu do Wołoch”92.

Jednoznacznie przeciw wojnie prowadzonej przez Koreckiego wypowiadał się kilkakrotnie Stanisław Żółkiewski ${ }^{93}$. Dziś z perspektywy jego wypowiedzi wydają się świadectwem rozwagi i rozsądku, jednak wówczas za tymi mądrymi wypowiedziami kryło się poparcie dla konkurencyjnej linii Mohyłów, o czym wiedziano, dlatego też hetman nie był w pełni wiarygodny. Wygląda na to, że hetman zdołał przekonać również króla na rzecz Gabriela Mohyły (poniekąd swojego wychowanka zamieszkującego w Żółkwi), którego wprowadził na dwór Zygmunta III. Świadczyć może o tym fakt, że poseł polski w Stambule oficjalnie zwrócił się do sułtana o mianowanie hospodarem mołdawskim Gabriela Mohyły ${ }^{94}$. Sułtan Ahmed nie zgodził się na tę propozycję, natomiast Gabriel niespodziewanie wykorzystał bunt na Wołoszczyźnie przeciw hospodarowi Radu Mihnii i objął tron, nie uzyskał jednak akceptacji sułtana. W 1618 roku ponownie został hospodarem wołoskim, tym razem oficjalnie i był nim przez dwa lata, jednak jego rządy nie przyniosły Rzeczypospolitej żadnego konkretnego pożytku. Przeciwnie, nawiązał kontakt z wrogim Polsce księciem siedmiogrodzkim Gáborem Bethlenem i po dymisji zamieszkał na stałe w Siedmiogrodzie.

Podsumowując wypada stwierdzić, że interwencje polskie w Mołdawii w końcu XVI i na początku XVII wieku były w istocie zgodne z interesem obydwu krajów, jakim było niedopuszczenie do wzmocnienia wpływów osmańskich z jednej strony i do otwartego konfliktu z Imperium Osmańskim z drugiej. Jan Zamoyski współpracując z królem Zygmuntem III w 1595 roku znakomicie wykorzystał sytuację, znajdu-

91 W. Syrokomla, Przyczynki do historyi domowej w Polsce, Wilno 1858, s. 8-9 (F. Kryski do Aleksandra Mohyły i F. Kryski do S. Koreckiego, 23.07.1616).

92 E. Hurmuzaki, Documente, supl. 2, t. 2, s. 399-407 (mowa Feliksa Kryskiego na sejmie, 27.04.1616).

93 Ibidem, s. 414-415 (Stanisław Żółkiewski do senatorów i szlachty, 25.07.1616).

94 A. Veress, Documente, t. 9, s. 110 (awizy z Wenecji, 09.07.1616). 
jąc optymalne rozwiązanie. Panowanie Jeremiego Mohyły gwarantowało utrzymanie polskich wpływów w Mołdawii, niezbyt głębokich, ale wystarczających by zapewnić istnienie skutecznego buforu między Rzeczpospolitą a Osmanami. Układ Szczęsnego Herburta z 1598 roku, zapewniający panowanie Jeremiemu Mohyle i jego potomkom dawał pewne szanse utrzymania tej kruchej równowagi, każde odstępstwo od niego, nawet w ramach rodu Mohyłów oznaczało osłabienie pozycji Polski, choćby przez konieczność nowych ustaleń w mniej korzystnej politycznie sytuacji. Nierozsądne rządy młodocianego Konstantego Mohyły pogrzebały jednak ten układ. Nie ulega wątpliwości, że młody hospodar zasłużył sobie na dymisję. Wyprawa w jego obronie podjęta została w złym momencie i, co gorsza, zakończyła się totalną klęską, co praktycznie wyeliminowało Rzeczpospolitą z wpływów w Mołdawii. Nie pogodzili się z tym liczni przedstawiciele polskiej elity, nie pogodzili się z tym również przebywający na emigracji w Polsce i niestety konkurujący ze sobą Mohyłowie. Ten ostatni fakt, a szczególnie zaangażowanie hetmana Stanisława Żółkiewskiego po stronie linii Symeona, niekorzystnie zaważył na losach interwencji zbrojnej z 1615-1616 r., która nie musiała skończyć się klęską. Wystarczyło odłożyć na bok osobiste sympatie i przynajmniej nie paraliżować działań konkurencji, w tym również politycznych w Imperium Osmańskim. Ostatecznie wypada stwierdzić, że utrata wpływów polskich w Mołdawii nastąpiła wówczas na własne życzenie.

\section{BIBLIOGRAFIA}

\section{Źródla archiwalne}

Archiwum Gtówne Akt Dawnych w Warszawie (AGAD)

Libri Legationum (LL) 26, 27

Archiwum Koronne Warszawskie AKW, dz. tur., kart. 484, nr 809

Archiwum Zamoyskich (AZ) 634, 857, 3028.

Biblioteka Jagiellońska, Kraków, rkps 102

Biblioteka Ossolineum, Wrocław, rkps 2354.

Biblioteka Kórnicka, rkps 324

\section{Źródla opublikowane}

Abrahamowicz Zygmunt, Katalog dokumentów tureckich, t. 1 (Dokumenty do dziejów Polski i krajów ościennych w latach 1455-1672), Warszawa 1959.

Ciorănescu Alexandru, Documente privitoare la istoria românilor culese din arhivele din Simancas, Bucureşti 1940.

Corfus Ilie, Documente privitoare la istoria românilor culese din arhivele polone. Secolul al XVI-lea, Bucureşti 1979.

Corfus Ilie, Documente privitoare la istoria românilor culese din arhivele polone. Secolele al XVI-lea şi al XVII-lea, Bucureşti 2001.

Corfus Ilie, Documente privitoare la istoria românilor culese din arhivele polone. Secolul al XVII-lea, Bucureşti 1983.

Corfus Ilie, Mihai Viteazul şi Polonii cu documente înedide în anexe, Bucureşti 1937.

Costin Miron, Latopis Ziemi Mołdawskiej i inne utwory historyczne, tłum., wstęp i komentarze Ilona Czamańska. 
Diariusze sejmowe z roku 1597, [w:] Scriptores Rerum Polonicarum, wyd. E. Barwiński, t. 20, Kraków 1907.

Elementa ad fontium editiones, t. 27, Romae 1972.

Heidenstein Reinhold, Dzieje Polski od śmierci Zygmunta Augusta do roku 1594 ksiag XII, przekład Michał Gliszczyński, Opole 2015.

Heidenstein Reinhold, Rerum Polonicarum ab excessu Sigismundi Augusti libri XII, Francofurti ad Moenum 1672.

Hurmuzaki Eudoxiu, Documente privitoare la istoria românilor, supl. 2, t. 2, București 1895.

Hurmuzaki Eudoxiu, Documente privitoare la istoria românilor, t. 3, cz. 1, București 1880; t. 3, cz. 2, Bucureşti 1889.

Jasnowski Józef, Dwie relacje z wyprawy Zamoyskiego pod Cecorę w r. 1595, „Przegląd Historyczno-Wojskowy" 1938 , t. 10, z. 2, s. 240-255.

Joppecourt Charles de, Histoire sommaire des choses plus memorables advenves aux derniers troubles de Moldavie ou sonr descrites plusieurs batailles gaignees tant par les princes polonois, que par les Turcs et Tartares, Paris 1620, wyd. I. Barret, [w:] Papiu-Illarian Alexandru, Tesauru de monumente istorice, t. 2, Bucureşti 1863.

Kołodziejczyk Dariusz, Ottoman-Polish diplomatic relations, Leyden-Boston-Köln 2000.

Otwinowski Jarosz, Powodzenia niebezpiecznego ale szczęśliwego wojska JKM przy JM Panu Staroście Kamienieckim w Multaniech opisanie prawdziwe przez Jarosza Otwinowskiego roku 1600, Kraków 1601.

Pisma Stanisława Żótkiewskiego kanclerza koronnego i hetmana, Lwów 1861.

Poselstwo Wojciecha Miaskowskiego do Turcji w 1640 r., opr. Adam Przyboś, Warszawa-Kraków 1985.

Szábó K., Bethlen Gábor fejedelem politikai levelezése, Magyar Történelmi Tár 1880, s. 486-488.

Syrokomla Władysław, Przyczynki do historyi domowej w Polsce, Wilno 1858.

Veress Andrei, Documente privitoare la istoria Ardealului, Moldovei şi Țării Românești, t. 4, București 1932; t. 5, Bucureşti 1932; t. 8 (1607-1613), Bucureşti 1935; t. 9 (1614-1636), București 1936.

Volumina Constitutionum, t. 2 (1550-1609), vol. 2 (1587-1609), wyd. Stanisław Grodziski, Warszawa 2008.

\section{Opracowania}

Bazylow Ludwik, Siedmiogród a Polska, 1576-1613, Warszawa 1967.

Bieńkowska Danuta, Michat Waleczny, Katowice 1975.

Bobicescu Cristian Antim, Unia, inkorporacja czy lenno? Kilka uwag o stosunkach Moldawii z Rzeczqpospolita podczas panowania Jeremiego Mohity (1595-1606), [w:] Rzeczpospolita w XVIIXVIII wieku. Państwo czy wspólnota?, red. B. Dybaś, P. Hanczewski, T. Kempa, Toruń 2007, s. 219-239.

Ciobanu Veniamin, Idei politice la Nestor Ureche: determinării, surse, motivaţii, „Anuarul Institutului de istorie A. D. Xenopol" 1992, t. 29, s. 300.

Ciobanu Veniamin, La cumpănă de veacuri (Ţările române în contextul politicii poloneze la sfirrşitul secolului al XVI-lea şi începutul secolului al XVII-lea), Iaşi 1991.

Condurachi I. D., Solii şi agenţi ai domnilor Moldovei la Poartă în secolul al XVII-lea, Bucureşti 1920.

Czamańska Ilona, Caracterul legăturilor lui Jan Zamoyski cu Movileştii, „Arhiva Genealogică” 1996, t. 3(8), nr 3-4, s. 307-312; toż [w:] Movileştii. Istorie şi spiritualitate româneasca, t. 1 (Casa noastra Movileasca), Sfânta Manastire Suceviţa 2006, s. 115-120.

Czamańska Ilona, Intre familie şi Stat. Relaţiile familiale ale dinastiei Movileştilor în Polonia, [w:] Movileştii. Istorie şi spiritualitate româneasca, t. 2 (Casa noastra Movileasca), Sfânta Manastire Suceviţa, 2006, s. 263-272.

Czamańska Ilona, Kampania mołdawska Samuela Koreckiego 1615-1616, [w:] Si vis pacem, para bellum. Bezpieczeństwo i polityka Polski. Księga jubileuszowa ofiarowana prof. Tadeuszowi Dubickiemu, red. Robert Majzner, Częstochowa-Włocławek 2013, s. 125-140. 
Czamańska Ilona, Orzet biały zwycięzca. ,,Wołoska Ziemia” Piotra Cieklińskiego - nowa próba interpretacji, [w:] Eruditio et interpretatio, Poznań 1997, s. 309-320.

Golimaș Alexandru, Lupta decisiva de la Tătăreni și la capitularea darabanilor deasupra Tăuteștilor, Iași 1935 .

Horn Ildikó, Andrzej Batory, Warszawa 2010.

Iorga Nicolae, Doamna lui Ieremia vodă, București 1910.

Iorga Nicolae, Istoria românilor, t. 5, wyd. 2, red. C. Rezachevici, București 1998.

Janiszewska-Mincer Barbara, Rzeczpospolita Polska w latach 1600-1603 (Narastanie konfliktu między Zygmuntem III Waza a stanami), Bydgoszcz 1984.

Milewski Dariusz, Między patronatem a wspótpraca - relacje Jana Zamoyskiego i hospodara mołdawskiego Jeremiego Mohyły, „Wieki Stare i Nowe” 2012, tom specjalny, s. 11-31.

Panaitescu Petru P., Mihai Viteazul, Bucureşti 2002.

Rezachevici Constantin, Bătalia de la „Cornul lui Sas” (3/13 iulie 1612). Reconstruire, „Studii şi Materiale de Istorie Militară" 1976, t. 9, 1976, s. 59-70.

Rezachevici Constantin, Două rectificări cronologice privind istoria Moldovei în veacul al XVII-lea, „Studii. Revista de istorie” 1972, t. 25, nr 2, s. 311-314.

Rotman-Bulgaru Cristina, Relaţiile Moldovei cu Imperiul Otoman la începutul secolului al XVII-lea, „Revista de Istorie” 1976, t. 29, nr 5, s. 676-696.

Rzońca Jan, Sejmy z lat 1597 i 1598. Część I: Bezowocny sejm z 1597 roku, Warszawa-Wrocław 1989.

Sas Józef, Wyprawa Zamoyskiego na Mołdawię, „Przegląd Powszechny” 1897, t. 56, nr 10, s. 74-89.

Skorupa Dariusz, Bitwa pod Bukovem 20 października 1600 r., [w:] Staropolska sztuka wojenna XVIXVII wieku. Prace ofiarowane prof. Jaremie Maciszewskiemu, red. Mirosław Nagielski, Warszawa 2002, s. 17-43.

Skorupa Dariusz, Stosunki polsko-tatarskie 1595-1623, Warszawa 2004, s. 62-63.

Spieralski Zdzisław, Awantury mołdawskie, Warszawa 1967. 